\title{
大気環境中におけるチタンの変色に及ぼす環境 および材料因子の影響
}

\author{
金子 道郎*・高橋 一浩*2 ・林 照彦*2・武藤 泉*2 ・徳野 清則*3 ·木村 欽一 *3
}

Environmental and Metallurgical Factors Affecting Discoloration of Titanium Sheets in Atmospheric Environments

Michio Kaneko, Kazuhiro Takahashi, Teruhiko Hayashi, Izumi Muto, Kiyonori Tokuno and Kinichi Kimura

\begin{abstract}
Synopsis : Effects of air bone salts, ultra violet (UV) irradiation, acid rain, impurity elements and TiC precipitated in surface layers of titanium on discoloration of titanium sheets were investigated to clarify the mechanism of discoloration of titanium in atmospheric environments. Air bone salts and UV irradiation did not enhance discoloration of titanium, but synthetic acid rain below pH 4.5 induced discoloration. The discoloration was largely enhanced by precipitation of $\mathrm{TiC}$ in surface layers of titanium sheets. It is considered that dissolved $\mathrm{Ti}^{\mathrm{H}^{+}}$from $\mathrm{TiC}$ by acid rain would deposit on titanium surface, inducing interferential color. Resistance to discoloration evaluated in accelerated discoloration tests was found to be remarkably improved by decreasing precipitation of TiC in surface layers of titanium sheets.
\end{abstract}

Key words : titanium; discoloration; acid rain; titanium carbide; atmospheric corrosion.

\section{1. 序論}

チタン板あるいは管は，その優れた耐食性を活かして， 化学プラント, 熱交換器, 食品工業等で使用されている。 また, 近年, チタン板は, 汎用ステンレス鋼が孔食を発生 する海浜地区の屋根あるいは壁材としても適用されるよう になって来ている。今までに，外装材に使用されたチタン 板に孔食, すきま腐食等の局部腐食が発生した例は報告さ れていないが, Fig. 1に示すように, 長期間暴露されたチ タン板の表面が暗い金色に変わるケースが報告されてい る。変色は, チタン表面の酸化チタン層の厚みが, ごく僅 かであるが増加した結果（数十 $\mathrm{nm}$ 以上）, 干渉作用によっ て生じるものであり, 屋根材としてのチタンの防食機能を 損なうものではない。ただし, 変色は, チタン外装材の意 匠性を損なう場合が考えられる。

ステンレス鋼の大気腐食では, 海塩粒子が腐食に極めて

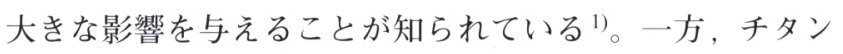
外装材の変色は, 海浜地区のみで発生しているわけではな く, 海塩粒子の影響の少ない内陸部でも発生して打り, チ タンの変色が海塩粒子によるとは考えにくい。チタンの建 材用途への適用は比較的最近であることから, 変色に関す る研究は必ずしも十分に行われているとは言い難く, その 発生機構はまだに不明な点が多い。

本研究では, 大気環境中に打けるチタンの変色機構を明
らかにすることを目的として，チタンの変色に及ぼす環境 因子として, 海塩粒子, 紫外線照射（以下, UVと略す） および酸性雨の影響を検討すると共に, チタン中の不純物 元素である酸素と鉄の影響およびチタン表面層での TiCの 析出の影響を検討した。
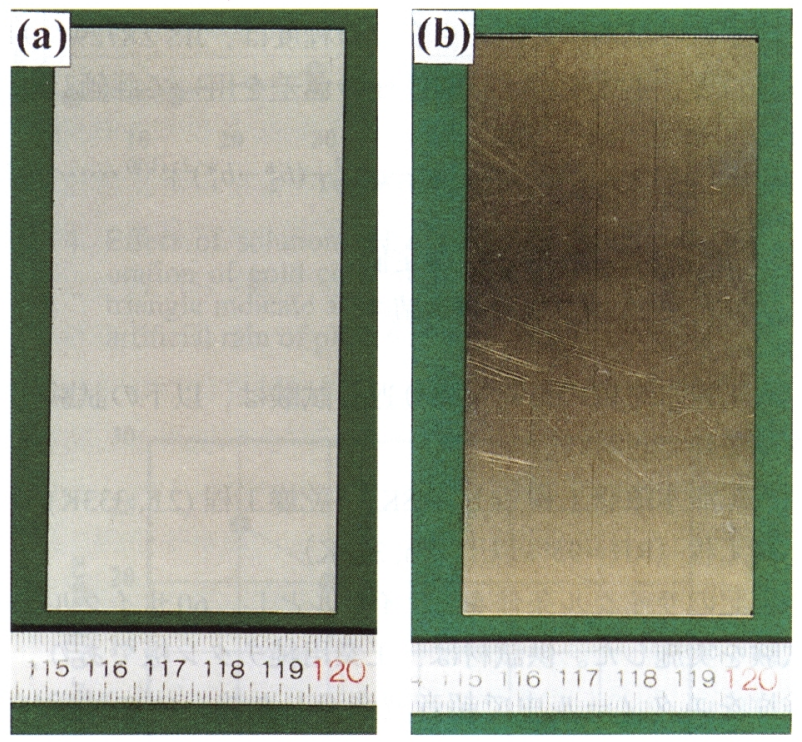

Fig. 1. Photographs of Ti sheets (a) not exposed and (b) exposed for 8 years in a country.

平成 15 年 2 月 28 日受付 平成 15 年 5 月 20 日受理 (Received on Feb. 28, 2003; Accepted on May 20, 2003)

* 新日本製鐵（株）鉄鋼研究所 (Steel Research Laboratories, Nippon Steel Corp., 20-1 Shintomi Futtsu 293-8511)

* 2 新日本製鐵（株）光技術研究部 (Hikari Technical Research Lab., Nippon Steel Corp.)

*3 新日本製鐵（株）チタン事業部 (Titanium Division, Nippon Steel Corp.) 
Table 1. Chemical composition of specimens tested (mass\%).

\begin{tabular}{|c|r|r|r|r|r|r|}
\hline Specimen & \multicolumn{1}{|c|}{$\mathrm{O}$} & \multicolumn{1}{c|}{$\mathrm{N}$} & \multicolumn{1}{c|}{$\mathrm{C}$} & \multicolumn{1}{c|}{$\mathrm{Fe}$} & \multicolumn{1}{c|}{$\mathrm{H}$} & $\mathrm{Ti}$ \\
\hline Grade1 and gold colored Ti sheets & 0.0473 & 0.0033 & 0.0069 & 0.014 & 0.0021 & Bal. \\
\hline Ti-O1 & 0.031 & 0.004 & 0.004 & 0.011 & 0.0037 & Bal. \\
\hline Ti-O2 & 0.087 & 0.004 & 0.005 & 0.035 & 0.0038 & Bal. \\
\hline Ti-O3 & 0.15 & 0.004 & 0.006 & 0.014 & 0.0039 & Bal. \\
\hline Ti-O4 & 0.23 & 0.004 & 0.005 & 0.007 & 0.004 & Bal. \\
\hline Ti-O5 & 0.27 & 0.004 & 0.007 & 0.008 & 0.0028 & Bal. \\
\hline Ti-O6 & 0.3 & 0.005 & 0.007 & 0.008 & 0.0029 & Bal. \\
\hline Ti-O7 & 0.43 & 0.008 & 0.006 & 0.001 & 0.0047 & Bal. \\
\hline Ti-Fe1 & 0.0048 & 0.004 & 0.008 & 0.012 & 0.001 & Bal. \\
\hline Ti-Fe2 & 0.0047 & 0.006 & 0.007 & 0.044 & 0.0007 & Bal. \\
\hline Ti-Fe3 & 0.053 & 0.007 & 0.008 & 0.094 & 0.0004 & Bal. \\
\hline Ti-Fe4 & 0.046 & 0.006 & 0.008 & 0.208 & 0.0008 & Bal. \\
\hline Ti-Fe5 & 0.054 & 0.006 & 0.005 & 0.42 & 0.0019 & Bal. \\
\hline
\end{tabular}

\section{2. 実験方法}

冷間圧延後，真空焼鈍を行った工業用第 1 種の純チタン 板と，さらに陽極酸化により金色に発色したチタン板およ び不純物元素としての鉄および酸素の影響を検討するた め，鉄および酸素濃度を変化させたチタン材を溶解し，鍛 造，熱間圧延後，冷間圧延し，真空焼鈍したチタン板を供 試材として用いた。供試材の化学成分を Table 1 に示す。 酸素あるいは鉄濃度を変化させた供試材では，屋外用途と して使用される工業用純チタンの Grade 1 の成分規格範囲 を十分満足させるように，酸素については，0.43質量％ま で，また，鉄濃度については，0.42質量％まで変化させた。 板厚は，いずれも $0.4 \mathrm{~mm}$ で，腐食試験用として主に $150 \times 75 \times 0.4 \mathrm{~mm}$ および $50 \times 25 \times 0.4 \mathrm{~mm}$ 寸法の試験片を機 械加工により作製した。前者の試験片は，人工海水を用い た乾湿繰り返し試験に用い，後者は，酸性雨中での浸漬試 験ならびにUV照射試験に供した。

いずれの試験においても変色の程度は, JIS Z8729 (1994) に基づき，下式に示す試験前後の色差を用いて評価した。

色差 $(\Delta E)=\left\{\left(L_{2}^{*}-L_{1}^{*}\right)^{2}+\left(a_{2}^{*}-a_{1}^{*}\right)^{2}+\left(b_{2}^{*}-b_{1}^{*}\right)^{2}\right\}^{(1 / 2)}$

$L_{1}^{*}, a_{1}^{*}, b_{1}^{*}$ は，試験前の測定值，

$L_{2}^{*}, a_{2}^{*}, b_{2}^{*}$ は試験後の測定值

人工海水を用いた乾湿繰り返し試験は，以下の試験サイ クル条件で行った。

人工海水噴霧工程 $(4 \mathrm{~h}, 308 \mathrm{~K}) \rightarrow$ 乾燥工程 $(2 \mathrm{~h}, 333 \mathrm{~K}) \rightarrow$ 湿 潤工程（RH=95\%以上, $2 \mathrm{~h}, 323 \mathrm{~K}$ ）

上記のサイクル条件を 1 サイクルとし，60サイクルまで 試験を実施した。供試材は，工業用純チタン板であり，試 験片をエタノール中で超音波洗浄した後，CCT試験に供 した。

UV照射の影響を調べる実験では，ガラス製の密閉容器 中に $30 \mathrm{cc}$ の土工海水を入れ，溶液中に板面を上にして $25 \times 50 \times 0.4 \mathrm{~nm}$ の試験片を浸漬し，その上部より主波長が $365 \mathrm{~nm}$ のUVを照射した状態で温度 $333 \mathrm{~K}$ の恒温槽内に保 持した。なお，試験は，42日間継続し，約 7 日ごとに照射
面の色彩測定を行い，変色に及ぼすUV照射の影響を検討 した。UVの照射強度は，測定波長 $350 \mathrm{~nm}$ において約 0.2 $\mathrm{mW} / \mathrm{cm}^{2}$ であった（照射強度の測定は，上記温度，湿度条 件で, 測定器のセンサー部分に同一のガラス容器の蓋をか ぶせた状態で行った）。なお，2002年10月16日（晴れ） に3階建ての当研究所の屋上（千葉県, 富津市）で測定し た太陽光の $350 \mathrm{~nm}$ の紫外線強度は, $0.2 \mathrm{~mW} / \mathrm{cm}^{2}$ であり， 上記実験での照射強度とほぼ同様であった。試験に用いた 供試材は， $50 \times 25 \times 0.4 \mathrm{~mm}$ 寸法の純チタン板で，試験前， エタノール中で超音波洗浄を行った。なお，比較試験とし て，UV照射をせずに，人工海水中で浸漬試験を実施した。 試験溶液，試験片寸法等は，同一とした。

変色に及ぼす酸性雨の影響を調べる実験では，大気中の $\mathrm{CO}_{2}$ が溶解した雨水を模擬した $\mathrm{pH} 5.6$ の溶液と硫酸によっ て pHを 3.7 に調製した模擬酸性雨の 2 種類を準備し，密閉 容器中にそれぞれ， $50 \mathrm{cc}$ の試験溶液を入れ，その中に試 験片を浸漬し，303Kの試験温度で実験を行った。本試験 では，陽極酸化法によって金色に発色した $50 \times 25 \times 0.4 \mathrm{~mm}$ の寸法のチタン板を用いた。なお，試験溶液は，実際の雨 水の測定結果 ${ }^{2}$ に基づいて組成を調整しており，pH 5.6の 雨水は, $127 \mu \mathrm{M} \mathrm{Na}_{2} \mathrm{SO}_{4}, 150 \mu \mathrm{M} \mathrm{NaNO}_{3}$ および $76 \mu \mathrm{M} \mathrm{NaCl}$ を含む。 $\mathrm{pH} 3.7$ の模擬酸性雨は, $160 \mu \mathrm{M}\left(\mathrm{NH}_{4}\right)_{2} \mathrm{SO}_{4}, 127$ $\mu \mathrm{M} \mathrm{H}_{2} \mathrm{SO}_{4}, 164 \mu \mathrm{M} \mathrm{NaNO}$ および $189 \mu \mathrm{M} \mathrm{NaCl}$ を含む。ま た，上記浸漬試験に加えて，硫酸および水酸化ナトリウム によって溶液の $\mathrm{pH}$ を 3 から 7 に変化させた溶液中での浸漬

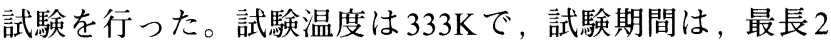
週間である。試験片寸法，溶液量は，上述の実験条件と同 様である。

また，変色に及ぼすチタン表面層に存在する $\mathrm{TiC} の$ 影響 を検討するため, $\mathrm{pH} 3$ の硫酸溶液中（測定温度：333K） において，市販の $\mathrm{TiC}$ (純度 $99 \%$ 以上）のアノード分極測 定を行った。掃印速度は， $20 \mathrm{mV} / \mathrm{min}$.で，測定中，アルゴ ンガスを吹込み，溶液を脱気した。なお，試験片の仕上げ は，\#600番のエメリ一紙を用いた湿式研磨である。

チタン表面の分析は, 主に表面X線回折，オージェ電子 分光分析装置（以下 $\mathrm{AES}$ と略記する）扎よびX線光電子 分光分析装置（以下，XPS と略記する）を用いた。 


\section{3. 実験結果}

\section{$3 \cdot 1$ CCT 試験および変色に及ぼす紫外線照射の影響}

CCT 試験における試験片の試験前後の色差と試験サイ クル数の関係を Fig. 2 に示す。CCT試験は，最長で 60 サイ クルまで実施したが，試験前後の色差は，40サイクル以 降，約 2 以下と極めて低く，60サイクル終了後の試験片と 未試験の試験片表面とを比較しても肉眼では，色彩変化は 全く確認できないレべルであった。本試験結果より，チタ ンの変色に及ぼす海塩粒子の影響は，極めて小さいものと 思われたので，次にUV照射の影響を検討した。

Fig. 3 は，変色に及ぼすUV照射の影響を検討した結果 を示す。試験温度 $333 \mathrm{~K}$ の工海水中に試験片を浸漬し， UV照射の有無の影響を最長で 42 日間評価したが，試験前 後の色差は，UV照射の有無に関わらず，非常に小さい值 であり，Fig. 1に示した写真のようにチタン表面が金色に 変色することは全く観察されなかった。以上，チタンの変 色に及ぼす塩化物およびUV照射の影響を検討したが，こ れらの環境因子によってチタンの変色が促進されることは なかった。以下に, 酸性雨の影響について, 検討を行った 結果について述べる。

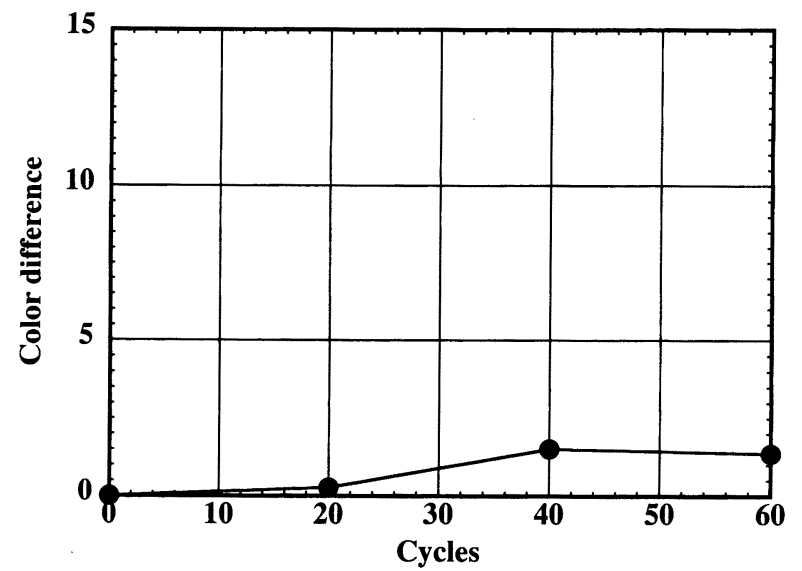

Fig. 2. CCT results of pure Ti sheets.

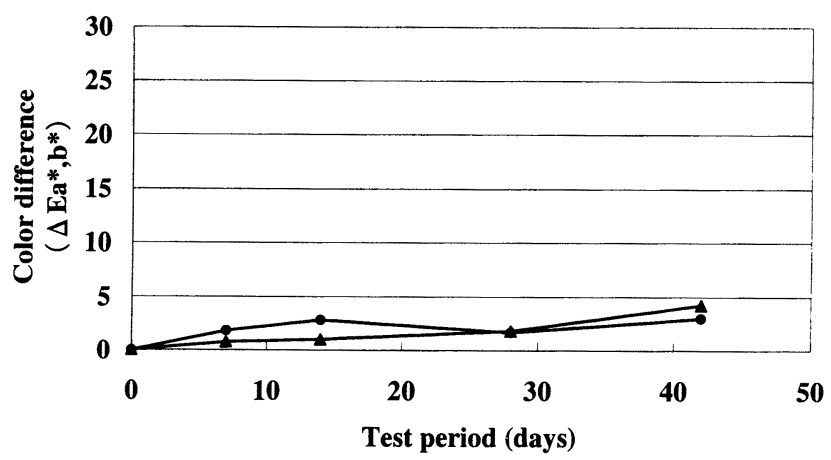

Fig. 3. Effect of UV irradiation on discoloration of pure Ti sheets in artificial sea water at $333 \mathrm{~K}$ : solid circle and triangle shows UV irradiation and no UV irradiation respectively.

\section{$3 \cdot 2$ 変色に及ぼす人工酸性雨の影響}

酸性雨の影響を調べる実験では, 金色の発色チタンを供 試材として, pH 5.6の模擬雨水と $\mathrm{pH} 3.7$ の模擬酸性雨中で 浸漬試験を実施した。試験結果を Fig. 4 に示す。試験開始 後, 約 30 日の期間は, いずれの溶液中においても, 試験 前後の色差は非常に低い值であったのに対して，それを超 えるあたりから，実験結果は大きく異なった。すなわち， $\mathrm{pH} 3.7$ の模擬酸性雨中では，試験時間と共に色差は大幅に 増加し, 約 70 日後では, 35近い色差となり, 試験後の試 料表面は, 紫色に変化した。一方, pH 5.6の溶液中では, 色差は長期間の試験後も低い值のままであり，試験後の目 視観察でも，変色は識別できなかった。 $\mathrm{pH} 3.7$ の模擬酸性 雨中での浸漬試験において，紫に変色した試験片について は，試験後酸化チタン層の厚みを AESで測定したところ， 試験前に比較して，明らかに厚みが増加していることが観 察された。チタンの 変色に酸性雨が大きな影響を及ぼす ことが判明したので，さらに，変色に及ぼす試験溶液の $\mathrm{pH}$ の影響を詳細に検討した。

Fig. 5 は, pHを 3 から 7 に変化させた $333 \mathrm{~K} の$ 溶液中に， 真空焼鈍材を 2 週間浸漬し，試験前後の色差を測定した結 果を示す。色差は，試験溶液の $\mathrm{pH}$ が約 4.5 以下となると大 きく増加し , Fig. 1 に示した写真と同様に, チタン表面が

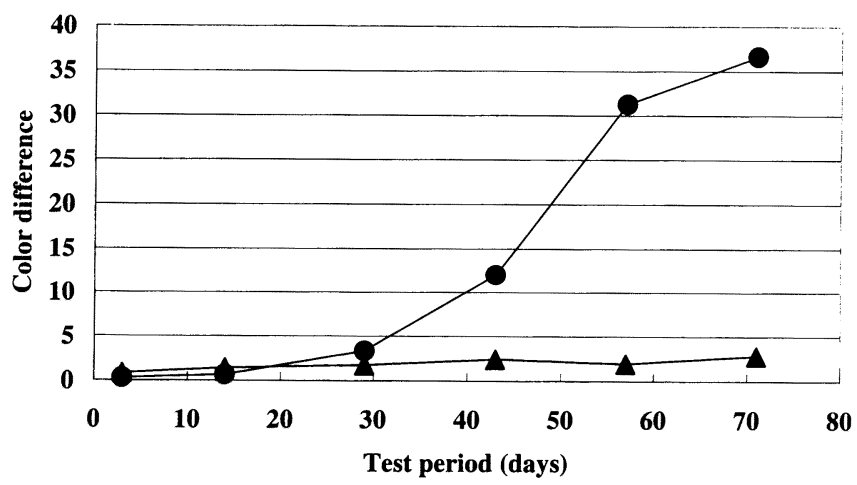

Fig. 4. Effect of solution $\mathrm{pH}$ of artificial rain on discoloration of gold colored Ti sheets: solid circle and triangle indicate artificially acid rain of $\mathrm{pH} 3.7$ and artificial rain of $\mathrm{pH} 5.6$ respectively.

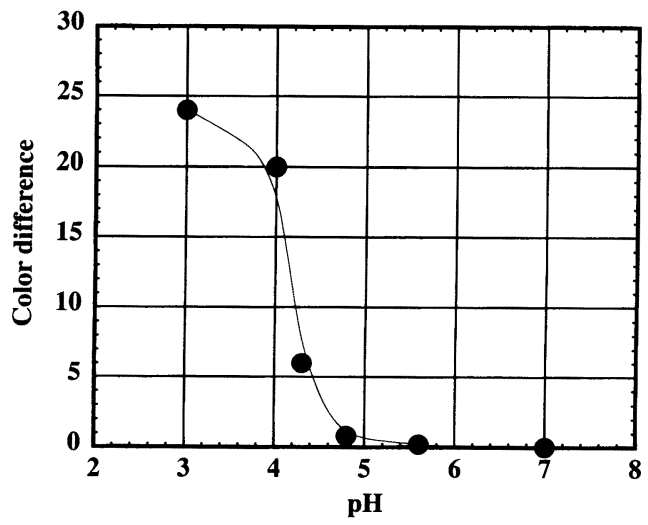

Fig. 5. Effect of solution $\mathrm{pH}$ on discoloration of pure $\mathrm{Ti}$ sheets in immersion tests at $333 \mathrm{~K}$ for $14 \mathrm{~d}$. 
金色に変色した。なお，本実験は，試験温度を $333 \mathrm{~K} て ゙$ 実 施しており，Fig. 4に示した実験結果の試験温度である $303 \mathrm{~K} よ り$ 高温であるため, pH 3の硫酸溶液中において， 純チタン板を用いて酸化チタン層の成長速度の温度依存性 を評価した。Fig. 6に試駼結果を示す。酸化チタン層の厚 みは，AESを用い，以下の手順で推定した。まず，アルゴ ンイオンを用いてチタン表面より深さ方向にスパッタリン グしながら，チタン，酸素濃度を測定し，酸素濃度が表面 付近の濃度と比較して, 約半分に低下したスパッタリング 時間を求めた，続いて，エリプソメーターによって厚みの 測定された $\mathrm{SiO}_{2}$ 標準試料を用いて，スパッタリング速度 を求め, この值と上述の酸素濃度が半減する時間との乗を 見掛けの酸化チタン層の厚みとした。なお，Fig. 6の縦軸 は, 試験後の酸化チタン層の厚みから, 試験に用いなかっ た真空焼鈍材の酸化チタン層の厚みの差を示す。Fig. 6 よ り明らかなように, 酸化チタン層の膜厚の成長速度は，ア レニゥスプロットに従っており，333Kでの浸漬試験は， 実際のチタン外装材表面の雨水がかかるような温度（外気 温度）での反応を促進しているものであり，チタンの変色 は，酸性雨によって変色が進行するものと推定される。

\section{$3 \cdot 3$ 変色に及ぼす材料因子の影響}

以上述べた実験結果より，大気環境中におけるチタンの 変色を促進する環境因子は，酸性雨であると考えられるた め, $\mathrm{pH} 3$ あるいは4の硫酸溶液中での浸漬試験によって， 変色に及ぼす材料因子の影響を検討した（硝酸あるいは， 硝酸と硫酸の混酸を用いた実験でも，同様な結果が得られ たため，以下の検討では，硫酸を用いて，pH 3 あるいは 4 に調整した溶液を用いた)。

Fig. 7は，純チタン板と純チタン板の表面を\#600のエメ リー紙で研磨したものを $333 \mathrm{~K}$ の $\mathrm{pH} 4$ の硫酸中で浸漬試験 した結果を示す。Fig. 7 より明らかなように，研磨材は， 研磨していないものと比較して, 明らかに耐変色性が向上 することが判明した。研磨材を再度，真空焼鈍し，同様な 変色試験に供した場合，耐変色性は，さらに向上したこと から，単に表面仕上げの違いが変色に影響しているのでは ないと考えられたため、これらの試験片について表面X線 回折測定を行った。その結果, いずれの試料とも金属チタ ンのピークに加えて，TiCのピークが観察され，そのピー ク高さは，耐変色性の優劣と同様に，純チタン板，研磨材， 研磨後，再度，真空焼鈍したチタン板の順に，低下するこ とが観察された。一例として，Fig. 8に，研磨していない 試験片（変色しやすい）の表面X線分析結果を示すが，明 らかにTiCのピークが検出されていることが分かる。なお， XPS を用いて，深さ方向の TiCの分布を調べたところ，チ タンの表面層のみ $(1 \mu \mathrm{m}$ 未満の範囲) に TiCが形成されて いることが観察された。Fig. 7に示した変色試験結果と表 面層における TiCの析出量の関係より, チタンの変色は, 表面層の TiCの形成が深く関係しているものと推定され

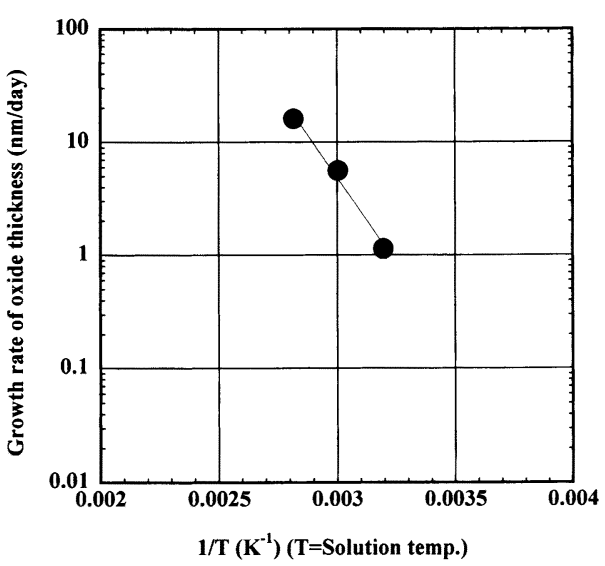

Fig. 6. Effect of test temperature on growth rate of titanium oxides on pure Ti sheets immersed in sulfuric acid of $\mathrm{pH} 3$

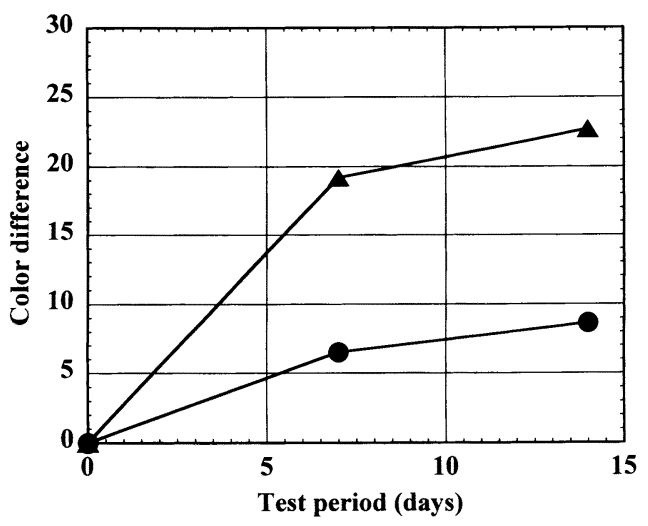

Fig. 7. Effect of surface finish on color difference of pure Ti sheets in sulfuric acid of pH 4 at $333 \mathrm{~K}$ : solid circle and triangle indicate Ti sheet polished by $\# 600$ grid paper and $\mathrm{Ti}$ sheets not polished respectively.

る。そこで， $\mathrm{TiC} の$ 影響を明確にするため，真空焼鈍材表 面を哨フッ酸溶液中で酸洗し, 数 $10 \mu \mathrm{m}$ 溶解させた後, \#600の湿式研磨を施したチタン板（寸法： $50 \times 25 \times 0.4 \mathrm{~mm}$ ) の半分の領域をアルミフォイルで被覆した状態で，炭素蒸 着を行い, 続いて, 真空焼鈍を行った。表面X線回折測定 によって，炭素蒸着を行った領域にTiCが形成されている ことを確認した後に，333Kの $\mathrm{pH} 3$ の硫酸溶液中で 2 週間 の浸漬試験を実施した。その結果を Fig. 9に示すが，炭素 蒸着を行い，その後の真空焼鈍によって表面層にTiCを形 成させた領域は，アルミフォイルで被覆した領域と比較し て，極めて変色しやすいことが判明した。

以上，チタン表面における TiC形成がチタンの変色を促 進することが判明したため, $\mathrm{pH} 3$ の硫酸溶液中における チタン（哨フッ酸溶液中で酸洗した後，\#600の湿式研磨 を行った）およびTiCのアノード分極曲線を測定した。測 定結果を Fig.10に示す。Fig.10より明らかなようにTiCは， チタン板と比較して, 遥かに大きな速度で溶解することが 明らかとなった。333Kの $\mathrm{pH} 3$ の硫酸溶液中（非脱気）に おけるチタン板の自然電位は，約 $100 \mathrm{mV}$ (vs. SSE)であり， 


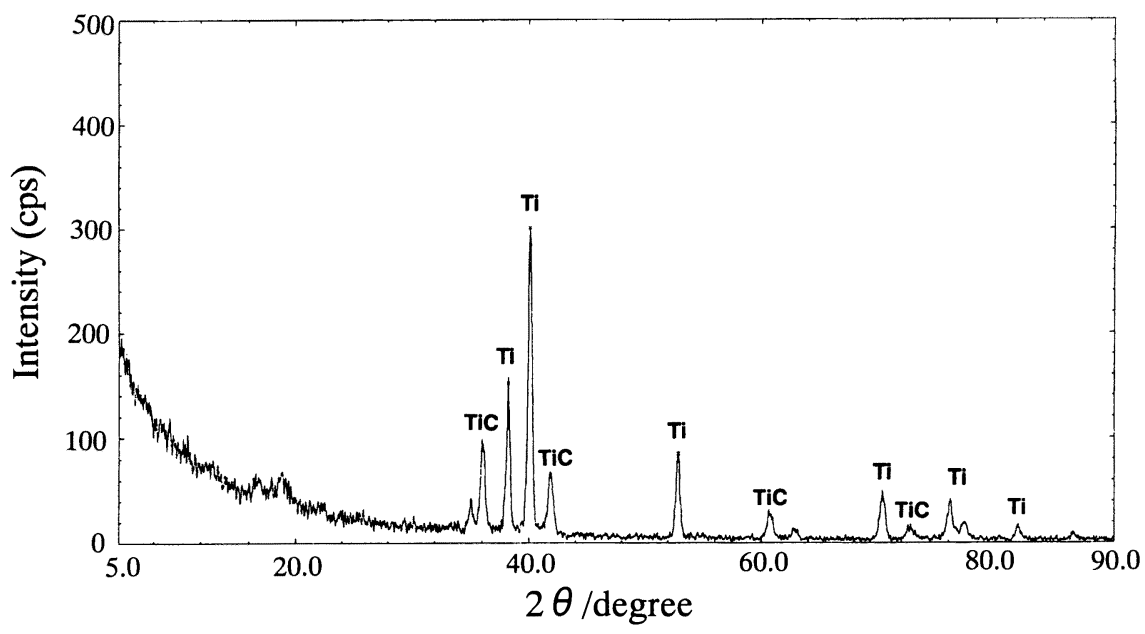

Fig. 8. X-ray diffraction pattern of pure Ti sheet.

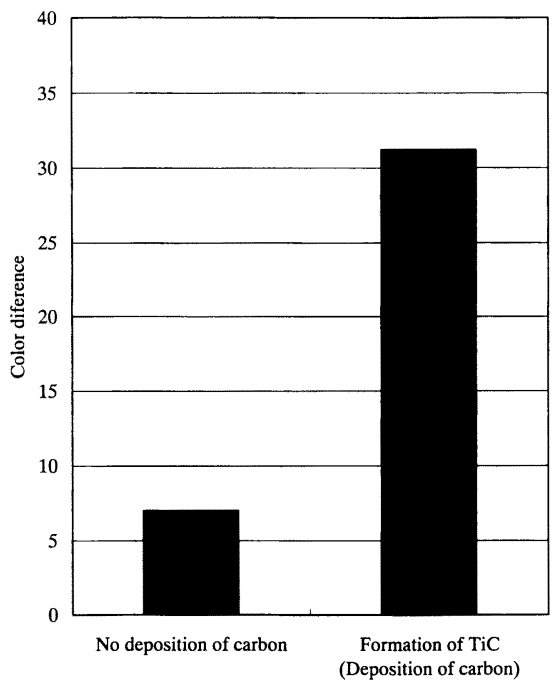

Fig. 9. Effect of $\mathrm{TiC}$ on discoloration of $\mathrm{Ti}$ sheets evaluated by discoloration test.

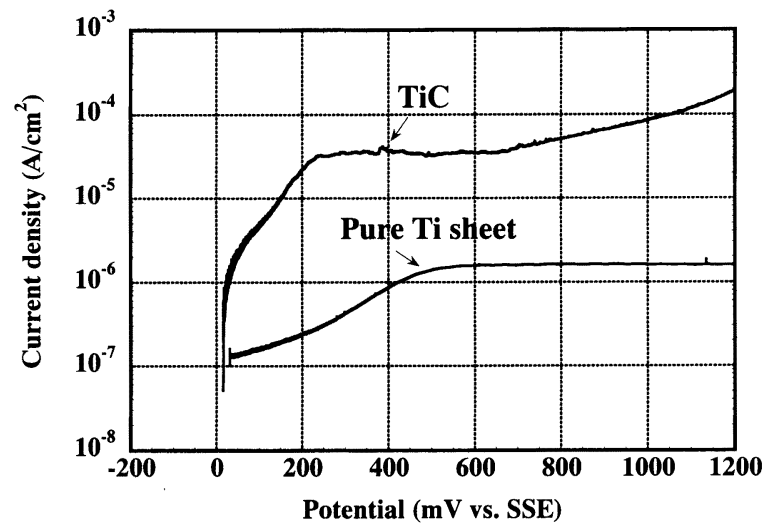

Fig. 10. Anodic polarization curves of pure Ti sheets pickled and polished, and $\mathrm{TiC}$ in sulfuric acid of $\mathrm{pH} 3$ at $333 \mathrm{~K}$.

この電位付近では, $\mathrm{TiC} は$, チタンと比較して, 1 桁以上 大きな速度で溶解することが分かる。

不純物元素の影響を調べる実験では，チタンの耐食性に
Table 2. Color difference of Ti sheets with oxygen or iron contents changed.

\begin{tabular}{|c|c|}
\hline Specimen & Color difference \\
\hline Ti-O1 & 11.2 \\
\hline Ti-O2 & 10.3 \\
\hline Ti-O3 & 10.6 \\
\hline Ti-O4 & 11.9 \\
\hline Ti-O5 & 10.6 \\
\hline Ti-O6 & 11.1 \\
\hline Ti-O7 & 11.3 \\
\hline Ti-Fe1 & 10.4 \\
\hline Ti-Fe2 & 10.4 \\
\hline Ti-Fe3 & 11.7 \\
\hline Ti-Fe4 & 10.7 \\
\hline Ti-Fe5 & 10.3 \\
\hline
\end{tabular}

影響を及ぼすことが報告されている鉄3)と工業用第 1 種の 純チタンの成分範囲の規格内で濃度範囲が大きい酸素につ いて検討した。チタン中の酸素濃度を $0.031 \%$ から $0.43 \%$ に変化させたチタン板および鉄濃度を $0.012 \%$ から $0.42 \%$ と変化させたチタン板を, $\mathrm{pH} 3$ および 4 の $303 \mathrm{~K}$ の硫酸溶 液中で浸漬試験を実施した。Table 2は，pH 3の333Kの硫 酸溶液中に 2 週間浸漬試験した時の試験前後の色差の測定 結果を示すが，試験前後の色差は，チタン中の酸素，鉄濃 度に影響されず，低い值を示すことが判明した。なお，試 験片の表面については， $\mathrm{TiC} の$ 影響を除くために研磨を行 い，最終，\#600のエメリー紙による湿式研磨によって仕 上げた。

以上述べたように，チタンの変色に及ぼす環境因子およ び材料因子として, 酸性雨およびチタン表面に析出した TiCの影響が極めて大きいことが明らかとなった。

\section{4. 考察}

ステンレス鋼の大気腐食においては，海洋より飛来する 海塩粒子の付着が，腐食の促進因子であることは，良く知 られている1)。一方，チタンは，ステンレス鋼と比較して 塩化物に対する耐食性が，遙かに優れることが知られてい 
るが，このことは，Fig. 2に示した人工海水を用いた CCT 試験において，チタンが変色を全く発生しない実験結果と 合致するものと考えられる。本実験条件における60サイ クルは, SUS304鋼の海浜地区での数年の暴露に相当する と考えられる厳しい促進試験であることから ${ }^{4)}$ ，本試験に おいて, 純チタン板に変色が全く発生しない実験結果は, 大気環境中におけるチタンの変色に対する海塩粒子の影響 は，小さいものと考えられる。なお，外装用チタン板の変 色は, 海塩粒子の影響が強い海浜地区でのみ発生している わけではなく，内陸部の都市，田園でも発生しており，本 実験結果は, 実際の変色発生の傾向とも合致するものと考 えられる。

チタンの優れた耐食性は，チタン表面の不働態皮膜に よっており，不働態皮膜は主として， $\mathrm{TiO}_{2}$ から構成されて いると考えられている ${ }^{5-7)}$ 。 $\mathrm{TiO}_{2}$ は，一般的に， $\mathrm{n}$ 型半導体 であり，そのバンドギャップは，結晶構造によって異なり， アナターゼ型では， $3.0 \mathrm{eV}$ ，ルチル型では， $3.2 \mathrm{eV}$ と報告 されている8)。したがって，約 $400 \mathrm{~nm}$ 以下の波長の紫外線 が照射された場合，ホールと電子対が形成され，空間電荷 層の曲がりによって，ホールは表面側，電子は内側に移動 するものと考えられる。ホールは酸化力が強いため, 各種 のラジカルを生成させ，チタンの変色に影響を与える可能 性が考えられる。しかしながら，Fig. 3に示したように， 人工海水中に打いて，日中の紫外線強度と，ほぼ同様な UVを 42 日間照射続けても，変色は照射材，非照射材とも 全く促進されなかったことから，チタンの変色へのUV照 射の影響も小さいものと考えられる。第1に，チタン表面 の不働態皮膜の厚みは，極めて薄いため，UV照射によっ て生成する電子とホール対の形成速度が小さく，変色に影 響を与えなかったことが考えられる。第2に，紫外線照射 によって形成された電子は，金属チタン側へ移動し，チタ ンの溶解反応を抑制した可能性が考えられる9)。

変色に及ぼす環境因子の影響として, Fig. 4, 5に示した ように，酸性雨の影響が極めて大きいことが判明した。 Fig. 5 より, 試験溶液の $\mathrm{pH}$ が約 4.5 以下となると, 試験前 後の色差が急激に上昇する，すなわち顕著な変色を発生す ることが分かる。一般的な酸性雨の定義は，大気中の $\mathrm{CO}_{2}$ が溶解した雨水が示す $\mathrm{pH} 5.6$ より低い雨を示すが，環境 省 ${ }^{10}$ が発表しているわが国の降水の平均 $\mathrm{pH}$ は，4.7 4.9 （調査期間は，平成 10 年 12 年，平成 5 年から 9 年もほほ 同様な平均 $\mathrm{pH}$ ）であり, $\mathrm{pH}$ が 4.5 以下の酸性雨が降る可 能性は, 日本全国で考えられる。したがって, 海浜地区, 内陸部に関わらず，チタンが変色する事例は，酸性雨が環 境因子とすれば，良く説明できる。ただし，Fig. 6に示し たように, チタン表面の酸化膜の成長速度には, 試験温度

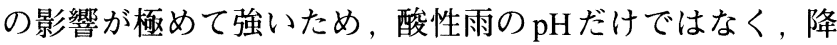
水時の気温が変色に大きく影響するものと考えられる。し たがって, 酸性雨の $\mathrm{pH}$ が低く, かつ, 平均気温の高い地
域が，最も変色が進行しやすい地域と考えられる。

次に酸性雨中におけるチタン表面の酸化膜の成長機構に ついて考察する。佐藤は, $\mathrm{pH} 2 \sim 4$ の塩酸溶液中における 高温（100 ${ }^{\circ}$ 以上）での浸漬試験において，チタン表面の 酸化膜厚みは，溶液の $\mathrm{pH}$ の低い方が厚いことを観察して おり，これは，チタンより溶出したチタンイオンが加水分 解によって酸化チタンを形成すると推定している7)。一方， 本実験では, 酸性雨中におけるチタンの変色は, 佐藤の研 究のような高温の浸漬試験ではなく，Fig. 4に示したよう に, 常温の $\mathrm{pH} 3.7$ の酸性溶液中で発生しており, しかも, Fig. 7, 9に示したようにチタン表面層にTiCが形成される 場合に著しく促進されており，酸性雨とチタン表面での $\mathrm{TiC}$ の析出とが変色発生の原因となっていると思われる。 滝らは，実機製造された真空焼鈍材のチタン板の表面層に $\mathrm{Ti}(\mathrm{C}, \mathrm{N})$ が形成されていることを報告しており ${ }^{11)}$ ，このよ うなチタン材は，塩酸のような非酸化性溶液中におけるチ タンの耐食性を向上させることを見いだしている。かかる 実験結果は，本研究結果と相反するものであるが，滝らの 研究結果は, チタンの不働態が維持できない塩酸溶液中で の試験であり，基本的にチタンの不働態が維持される溶存

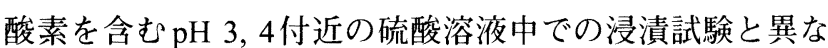
る環境であり，耐食性に及ぼす $\mathrm{Ti}(\mathrm{C}, \mathrm{N})$ あるいは $\mathrm{TiC}$ の影響 が異なることが考えられる。すなわち，チタンの不働態皮 膜が維持される酸化性の環境においては，チタン含有量の 低い $\mathrm{TiC}$ 層は，チタン素地に比較して，耐食性に劣るため， 素地よりも速い溶解速度を示すものと考えられる。すなわ ち, チタンの変色は, 酸性雨によってチタン表面に存在す る TiCが容易に溶解し，溶出したチタンイオンがチタン表 面に加水分解によって多孔質の $\mathrm{TiO}_{2}$ あるいは $\mathrm{TiO}_{2} \cdot n \mathrm{H}_{2} \mathrm{O}$ と して析出し，干渉色を呈するものと考えられる。なお，酸 性雨中において，TiCの耐食性が素地のチタンより劣るこ とは，Fig.10に示したように，TiCの $\mathrm{pH} 3 ， 333 \mathrm{~K}$ の硫酸溶 液中に打けるアノード電流密度が，チタンと比較して遥か に高い值を示す結果から支持されるものと思われる。本研 究では，溶出したチタンイオンが，いかなる過程を経て加 水分解反応によって， $\mathrm{TiO}_{2}$ として析出するか明らかにする ことはできなかったが，たとえば，下記の(2)あるいは $(3)^{12}$ 式の反応によって, 溶出チタンイオンが, 加水分解 により $\mathrm{TiO}_{2}$ を形成するとし，腐食電位を $0.1 \mathrm{~V}$ ( vs. SSE) と 仮定すると， ( 2 )式より $\mathrm{pH} 3$ で平衡する $\mathrm{Ti}^{3+}$ 濃度は, 約 $10^{-28} \mathrm{M}$ であり，また，(3)式より $\mathrm{pH} 3$ では，平衡する $\mathrm{TiO}^{2+}$ 濃度は，約 $10^{-21} \mathrm{M}$ となる。

$$
\begin{aligned}
& \mathrm{Ti}^{3+}+2 \mathrm{H}_{2} \mathrm{O}=\mathrm{TiO}_{2}+4 \mathrm{H}^{+}+\mathrm{e}^{-} \\
& \mathrm{TiO}^{2+}+\mathrm{H}_{2} \mathrm{O}=\mathrm{TiO}_{2}+4 \mathrm{H}^{+}
\end{aligned}
$$

実際に，加水分解反応を生じるには，上記チタンイオン 濃度が，平衡濃度を超え，過飽和となることが必要である 


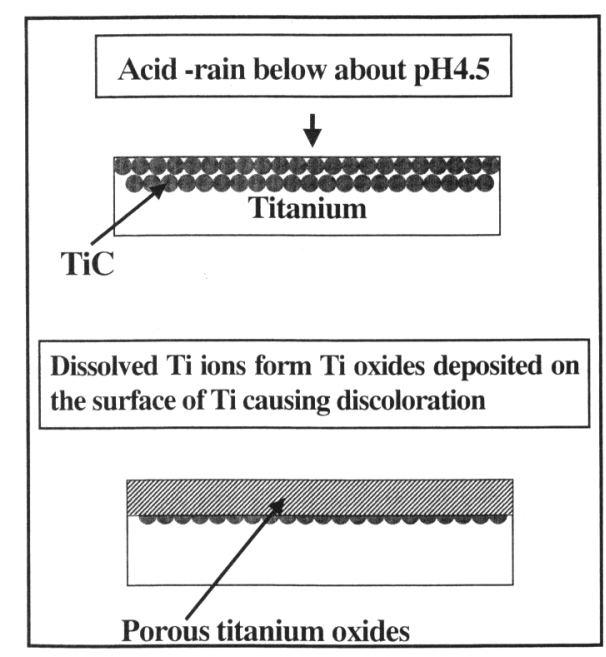

Fig. 11. Schematic diagram of discoloration of $\mathrm{Ti}$ in atmospheric environments.

と考えられるが, Fig.10に示したように，チタン表面に $\mathrm{TiC}$ が析出して, 溶解速度が増加しているとすると, 十分, (2), (3)式の反応により， $\mathrm{TiO}_{2}$ をチタン表面に形成する可 能性は十分, 考えられる。

なお， $\mathrm{TiC} の$ 構成元素である炭素についてであるが，硫 酸を用いた変色試験後あるいは，実際の大気環境中で変色 したチタン板表面の AES 分析を行った結果では, 酸化チ タン層と同じ位置より検出される炭素濃度は, 試験前, 暴 露前の状態と比較して, 極めて低い濃度であることから, $\mathrm{TiC}$ 中の炭素は, $\mathrm{CO}_{2}$ あるいは炭酸として溶出しているも のと推察される。Fig.11に, 本研究より得られた大気環境 中に打けるチタンの変色機構の模式四を示す。チタン表面 近傍の $\mathrm{TiC}$ 析出状態は, 抽出レプリカ試料を用いた透過 電子顕微鏡観察（以下 TEM 観察と略す）あるいは，断面 TEM観察によると, 数十 $\mathrm{nm}$ の寸法の塊状の TiCが析出し ており, Fig.11はこのような寸法の TiCが溶解し, 数十 nm の酸化チタン層を形成する様子を模式的に示すものであ る。Fig.12は, 屋外環境で使用され暗い金色に変色したチ タン板の走査型電子顕微鏡写真を示す。チタン表面形態は, 極めて微細な酸化物が析出した様相を呈しており， $\mathrm{TiC} よ$ り溶出したチタンイオンが加水分解によってチタン表面に 析出するモデルを支持する観察結果と考元られる。本試料 の表面をXPS 分析および表面X線回折を実施すると, XPS 観察からは, $\mathrm{TiO}_{2}$ に相当するピークが検出され, 表面 X線 回折では, 一部, アナターゼ型酸化チタンのピークが検出 されている。

以上の検討結果より, 大気環境中におけるチタンの耐変 色性を向上させるには，チタン表面層での TiCの形成を抑 制することが不可欠となると考えられる。チタン表面での TiCの形成は, 冷間圧延工程での圧延油に起因すると考え られることから，圧延油を起因とした TiC形成を抑制した 真空焼鈍仕上げのチタン板を実機製造し，かかる製造材の

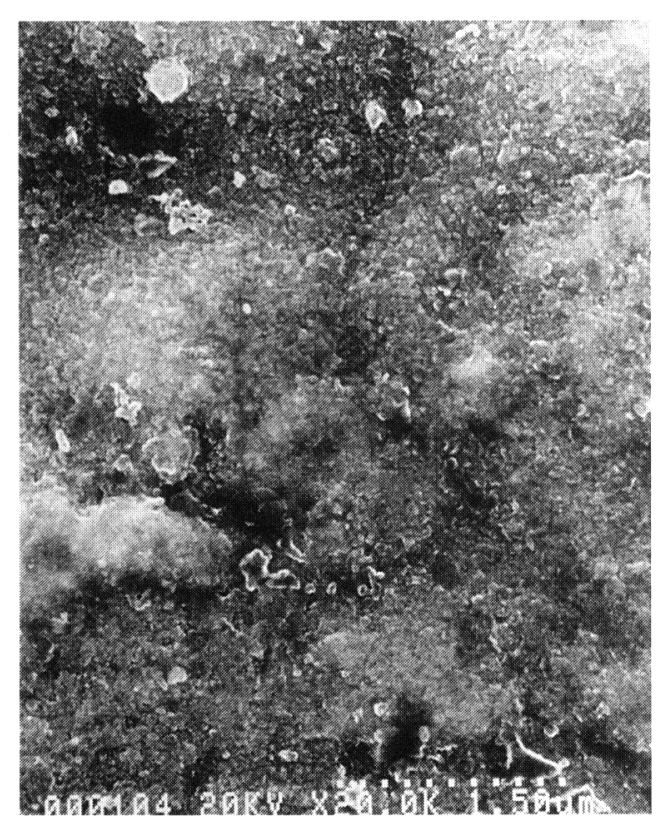

Fig. 12. SEM microphotographs of discolored Ti roof exposed for 10 years.

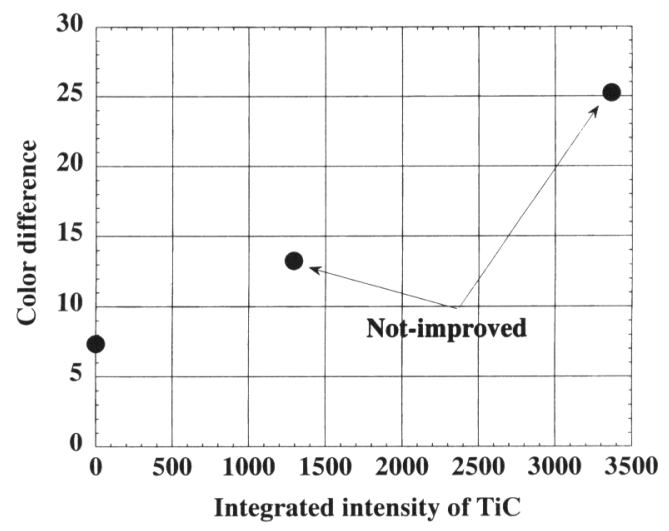

Fig. 13. Effect of $\mathrm{TiC}$ precipitates on discoloration of $\mathrm{Ti}$ sheets in sulfuric acid of $\mathrm{pH} 3$ at $333 \mathrm{~K}$ for 2 weeks.

耐変色性を $\mathrm{pH} 3$ の硫酸溶液中における2週間の浸漬試験に よって評価した。Fig.13は, 実機製造材の耐変色性とチタ ン板表面の $\mathrm{TiC}$ の析出量（同一条件下での薄膜 X線回折法

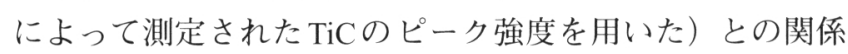
を示す。Fig.13より明らかなように， TiCの析出を抑制す ることによって, チタン板の耐変色性を大幅に改善できる ことが分かる。なお, 薄膜 X線測定において, $\mathrm{TiC} の$ 析出 が観察されていないチタン板に扎いても, 試験後, 約 7 程 度の色差を示しているが，これは，極微量であるが，チタ ン表面によりチタンが溶解し, 極薄い酸化チタン層を形成 したことによると考えられる。

\section{5. 結論}

チタンの変色は, CCT 試験およびUV照射を行った人工 
海水中での浸漬試験とも，全く発生せず, $\mathrm{pH}$ が約 4.5 以下 の酸性溶液中での浸漬試験によって発生し, 特にチタン表 面にTiCが形成されている場合に，変色が著しく促進され ることが明らかとなった。大気環境中におけるチタンの変 色は，酸性雨によってチタン表面層の $\mathrm{TiC}$ の溶解が促進さ れ，溶出したチタンイオンが多孔質な $\mathrm{TiO}_{2}$ (あるいは $\left.\mathrm{TiO}_{2} \cdot n \mathrm{H}_{2} \mathrm{O}\right)$ として析出し，干渉作用で変色するものと考 えられる。

また，TiCの析出を抑制したチタン板は，酸性雨の影響 を取り込んだ変色促進試験において，優れた耐変色性を示 すことが確認された。

\section{文献}

1 ）ステンレス鋼便覧，第3版，ステンレス協会編，日刊工業新聞
社, 東京, (1995), 306.

2 ) N.Tagomori, H.Kihira, K.Kinoshita, T.Nakamura and S.Soeda: Proc. JSCE CORROSION'94, JSCE, Tokyo, (1994), 201.

3 ) W.R.Fischer: Werkst. Korros., 12 (1961), 597.

4 ) I.Muto, E.Sato and S.Itou: Corros. Eng. (Jpn)., 42 (1993), 211.

5 ) J.Yahalom and J.Zahavi: Electrochim. Acta, 15 (1970), 1429.

6 ) C.K.Dyer and J.S.L.Leach: J. Electrochem. Soc., 125 (1978), 1032.

7 ) 佐藤廣士：九州大学工学研究科博士論文, (1983).

8 ) 清野 学著: 酸化チタン 物性と応用技術, 技報社, 東京, (1991), 66.

9 ) T.Imaoka, R.Fujisawa, A.Suda and S.Tsujikawa: Corros. Eng. (Jpn)., 43 (1994), 482.

10) 第4次酸性雨対策調查取りまとめ, 酸性雨対策検討会編, 環境 省, 東京, (2002).

11) Y.Mitsuyoshi, C.Taki, Y.Shinra and H.Sakuyama: CAMP-ISIJ, 2 (1989), 1320.

12) M.Pourbaix: Atlas of Electrochemical Equilibria in Aqueous Solutions, NACE, Texas, (1974), 213. 